\title{
Impacts of Exchange Rate and Economic, Political, Cultural, Infrastructural, and Environmental Indicators on Tourism in Iran
}

\author{
Impactos da taxa de câmbio e indicadores econômicos, políticos, \\ culturais, de infraestrutura e ambientais no turismo no Irã
}

\author{
Ali Sarchami'(i), Mohsen Zayandehrodi'(i), Seyyed Abdulmajid Jalaee ${ }^{\prime \prime}(\mathbb{D}$ \\ I Islamic Azad University of Kerman, Iran \\ "University of Kerman, Kerman, Iran
}

\begin{abstract}
Known as the second most profitable industry worldwide, tourism is now very important to states and can have a prominent role in their economic growth. Therefore, it is necessary to analyze the factors affecting tourism. In addition to the exchange rate, these factors include economic, political, cultural, infrastructural, and environmental indicators, all of which were analyzed in this study. For this purpose, a vector autoregressive (VAR) model was developed to analyze data of Iran from 1981 to 2018. According to the research findings, the exchange rate and economic, political, cultural, infrastructural, and environmental composite indicators had significant impacts on Iran's tourism revenue.
\end{abstract}

Keywords: Exchange rate; Composite indicators, Tourism revenue

\section{RESUMO}

Conhecida como a segunda indústria mais rentável do mundo, o turismo agora é muito importante para os estados e pode ter um papel de destaque em seu crescimento econômico. Portanto, é necessário analisar os fatores que afetam o turismo. Além da taxa de câmbio, esses fatores incluem indicadores econômicos, políticos, culturais, de infraestrutura e ambientais, todos analisados neste estudo. Para esse fim, um modelo de vetor autoregressivo (VAR) foi desenvolvido para analisar os dados do Irã de 1981 a 2018. De acordo com os resultados da pesquisa, a taxa de câmbio e os indicadores compostos econômicos, políticos, culturais, de infraestrutura e ambientais tiveram impactos significativos sobre o Irã. receita de turismo.

Palavras-chave: Taxa de câmbio; Indicadores compostos; Receita de turismo 
Generally, the tourism industry has direct and indirect benefits. A direct benefit is a substantial increase in a country's foreign exchange earnings because the arrival of every tourist brings a considerable amount of earnings to the destination country. Given the special conditions of Iran, if ecotourism and rural tourism are developed, a significant part of earnings can be allocated to the underdeveloped areas in order to improve their local businesses. Hence, Iranian-Islamic tourism development can significantly affect even poverty mitigation in the underdeveloped areas of Iran. However, regarding the indirect benefits of Islamic tourism, it should be emphasized that developing tourism in Iran can greatly neutralize the atmosphere of Iranophobia and Islamophobia, publicized by the Western powers on the international media. Thus, these indirect impacts are even parallel with the cultural goals of the Islamic Revolution. It should also be emphasized that changing this atmosphere can encourage foreign investors to participate in Iran's economy (FATAHI, 2017).

Since it is accepted that tourism brings considerable revenue to countries and that it is a way of economic development, it is necessary to analyze the factors affecting the tourism industry. These factors include the exchange rate and economic, political, cultural, infrastructural, and environmental indicators (AGIOMIRGIANAKIS et al. , 2016).

Apart from the impact of the exchange rate on international tourism, it is believed that increasing the exchange rate will also affect domestic tourism. Some believe that there will be positive impacts, whereas some others consider the impacts negative. According to some experts, increasing the exchange rate will decrease the departure rate of domestic tourists and will help domestic tourist destinations thrive. However, some other experts disagree because, according to the annual report published by the World Travel \& Tourism Council (WTTC) every ten years to analyze the tourism status and its economic impacts on 181 countries, Iran showed \%3.9 of growth in the global tourism industry and will encounter a recess and reach \%3.8 by 2020. In addition, Iran's tourism revenue was nearly 2.4 billion dollars, accounting for $\% 2.5$ of Iran's total exports, in 2010. It is predicted that this revenue will reach 5.1 billion dollars, 
accounting for \%4.2 of Iran's total exports, in 2010. According to the WTTC, 598000 individuals started working in Iran because of the tourism industry. This number accounts for $\% 8.3$ of all jobs in Iran. It is also predicted that there will be 726000 individuals working in the tourism industry by 2020 . This number will account for $\% 2$ of all jobs (MOHAMMADI et al., 2010).

It is then fair to conclude that the exchange rate is one of the factors affecting tourism. Therefore, this study analyzed the impacts of the exchange rate and economic, political, cultural, infrastructural, and environmental composite indicators on tourism in Iran. The main research question is how the exchange rate and economic, political, cultural, infrastructural, and environmental composite indicators affect tourism in Iran.

This paper first addresses the theoretical foundations on the relationship between the exchange rate and tourism. Then the empirical research background is reviewed in two sections, i.e. domestic background and foreign background. After that, the research model and variables are introduced. Then the research model is estimated, and relevant tests are conducted. Finally, the results are analyzed, and the conclusion is drawn.

\section{RESEARCH BACKGROUND}

Tamizi and Shahbazi (2018) conducted a study entitled Analyzing the Impact of Exchange Rate Shock on Iran's Tourism Sector. They first used the data of the official exchange rate to obtain the exchange rate shock through autoregressive conditional heteroskedasticity and generalized autoregressive conditional heteroskedasticity (ARCH/GARCH) models. Then they employed the time series data pertaining to the period 1981-2015 through the autoregressive distributed lag (ARDL) model to estimate the long-term and short-term relationships of the research variables. According to the estimation results, there was a negative significant relationship between the exchange rate shock and tourists arriving in Iran. Furthermore, the exchange rate shock had positive significant relationships with the GDP and the consumer price index. 
Masoum Zadeh and Shirafkan Lamsou (2017) carried out a study entitled Analyzing Impacts of Exchange Rate Regimes on International Tourism Flow in Selected Islamic Countries: Gravity Approach. They employed the gravity approach and panel data to estimate the number of international tourists arriving in the selected Islamic countries including Bahrain, Iran, Iraq, Egypt, Turkey, Saudi Arabia, the UAE, Kuwait, Qatar, Yemen, Syria, Lebanon, Jordan, and Oman from 1993 to 2013. Their research results showed that the fixed exchange rate regime had a positive significant impact on the tourism flow and that maintaining the exchange rate stability had a major role in attracting international tourism. Other factors having positive impacts on the tourism flow included commerce, GDP, distance, population, common languages, and colonization, whereas the effective exchange rate, nominal exchange rate, and joint business agreements had negative impacts on the tourism flow. All of the coefficients were statistically significant except for being a colony and having a join business agreement.

Rasekhi and Mohammadi (2017) conducted a study entitled Factors Affecting Tourism Demand in the Caspian Sea Countries. They employed panel data of countries bordering the Caspian Sea from 2000 to 2013. Their research results indicated that per capita income, actual exchange rate, and business liberalization had positive impacts on tourism. However, economic instability had a negative significant impact on tourism demands.

Niazi and Rezaei (2015) conducted a study entitled Impact of Exchange Rate Shock on International Tourism Flow in Iran. This paper addressed the effect of the exchange rate shock on the international tourism flow to Iran from 1971 to 2011. For this purpose, ARCH/GARCH models were first employed to extract the exchange rate shock. Then the Johansen-Juselius co-integration method was utilized to extract the relevant long-term relationship. Their research results indicated that (1) the elasticity of the number of foreign tourists entering Iran in comparison with GDPs of countries having tourism relationships with Iran was +34.06 . This finding shows that foreigners 
considering visiting Iran a luxurious trip. It also shows the importance of per capita GDP and its growth in countries whose citizens visit Iran. In addition, (2) the elasticity of foreign tourists entering Iran was -3.56 in comparison with the ratio of Iran's consumer price index to the consumer price indices of countries whose citizens travel to Iran. Moreover, the exchange rate shock has a negative impact on the arrival of tourists in Iran; however, its coefficient is -0.0013 , which shows that the impact is negligible.

Adhi Nugroho et al. (2017) carried out a study entitled Impacts of Exchange Rate Shock on Tourism Sector. According to their research findings, the exchange rate shock had no impact on foreign tourists' decisions on account of the fact that the arrival of foreign tourists increases regardless of the exchange rate shock (value increase or value decrease).

Ergen and Yavuz (2017) conducted a study entitled Variable Effects of Exchange Rate Volatility on Inflation of Tourists in Turkey. According to their research results, tourism trend in Turkey included 16 million tourists in 2003 and reached 40 million tourists in 2015. Nonetheless, although the tourism flow and total revenue increased, per capita expenses decreased. In recent years, tourism revenue has accounted for over $\% 4$ of revenue and nearly $\% 20$ of entire exports in Turkey. Therefore, exchange rate volatility must be minimized in Turkey so that tourism policies can have positive outcomes.

Agiomirgianakis et al. (2016) carried out a study entitled Impacts of Exchange Rate Shocks on Tourism Flows in Iceland. They analyzed the effect of exchange rate variable (ERV) on the arrival of tourists in Iceland from the first quarter of 1990 to April 4, 2014. They employed the ARDL method for data analysis. Their research findings generally indicated that uncertainty had a negative effect on the arrival of tourists in Iceland.

Ehigocho et al. (2016) conducted a study entitled Exchange Rate Shock and Tourism Product in Nigeria. They analyzed the effects of exchange rate shock on tourism production sector in Nigeria from 1995 to 2015 by using the vector error correction model (VECM) and the Granger causality test. Their research results 
indicated that exchange rate shock had a negative effect on tourism GDP in Nigeria and that increasing shocks would decrease the share of tourism in GDP. According to the Granger causality test results, there were two-way causality and long-term relationships between the share of tourism in GDP and the share of tourism in employment as well as the actual effective exchange rate and the international arrival rate of tourists.

Akay et al. (2015) carried out a study entitled Effects of Exchange Rate and Revenue on Tourism Payment Balance in Turkey from 1998 to 2011, in which they employed the VECM. According to their results, the exchange rate and foreign revenue had positive effects on the tourism payment balance, whereas domestic revenue had a negative effect on this payment balance, and there was no J curve.

Kilic and Bayar (2014) conducted a study entitled Effect of Actual Volatility Rate Variable on Tourism Revenue and Expenses in Turkey from 1994 to 2013. For this purpose, they employed GARCH $(1,1)$ to identify the effect of the exchange rate shock variable on tourism revenue and expenses in Turkey. According to the results, the actual effective exchange rate had a positive relationship with tourism revenue and expenses in the long run.

Thompson et al. (2013) carried out a study entitled Effect of Actual Exchange Rate on the US Tourism Payment Balance from 1973 to 2010 by using the VECM and instant reaction functions. Their research results showed that decreasing the exchange rate affected the tourist exportation revenue but not the tourist important revenue. The tourists who left the US reacted to the revenue; however, those who entered the US showed no reactions to the revenue.

According to the empirical research findings, the exchange rate and economic, political, cultural, infrastructural, and environmental indicators can affect tourism. It is necessary to analyze their interplay based on statistical data, something on which the following sections focus. 


\section{THEORETICAL FOUNDATIONS}

\subsection{Factors Affecting Tourism Demand}

The most important factors affecting tourism demand include specific variables such as domestic service and commodity consumer price index, per capita actual income, and economic openness degree, each of which is explained in this section (ERGEN, EREN, YAVUZ, AND ERSIN, 2017).

\section{1.1 Consumer price index:}

The consumer price index is one of different price indices used as a criterion for measuring price changes of a constant and certain number of products and services consumed by urban families. It is also a tool utilized to measure the general level of prices on the retail market. In addition, it is one of the best instruments employed to evaluate inflation rate and the purchase power of a country's currency. This index estimates the cost-of-living index. The consumer price index of a portfolio considers its items and importance coefficients determined in the basic year. Theoretically, the expected consumer price index is negative because tourist services become expensive as the domestic consumer price index have to increase prices. As a result, the number of foreign tourists drops down.

\section{1. 2 Actual per capita revenue:}

Theoretically, increasing the actual per capita income of a country increases the demand for international tourism in that country. Therefore, the expected sign of this variable is positive.

\section{1. 3 Market exchange rate:}

When the exchange rate increases, the value of a country's currency decreases. Therefore, the prices of tourist goods and services will be low to foreign tourists in a 
host country, and the number of tourists will increase. Thus, the market exchange rate is considered positive.

\section{1. 4Economic openness degree:}

Defined as the total share of foreign trades (exports + imports) in GDP, the economic openness degree indicates to what extent a country has business interactions with other countries. Increasing the economic openness degree increases a country's business interactions with the world. When there are more economic opportunities along with improved and expanded business relationships with other countries, political and cultural relationships develop among countries. This can help increase the arrival of tourists (known as traders) in a country. Therefore, it is expected that the openness degree is a positive variable.

However, like many other industries, the exchange rate shock has confused the tourism industry. This confusion is much more tangible in the tourism market than in other industries because the tourism industry is directly related to the exchange rate volatility. Tourists need to exchange their money into euro or dollar whether they leave or enter Iran, something which increases the effect of exchange rate shock on the tourism market. Prior to 2011, low actual exchange rates made the foreign tourist destinations low-cost to domestic tourists; as a result, more and more foreign trips were taken during those years. Increasing the nominal exchange rate and its actual exchange rate has led to the incredible attraction of foreign tourists because Iran is now considered an inexpensive destination for tourists. Therefore, it is evident that the exchange rate can affect the tourism sector.

\subsection{Empirical Evidence for Effectiveness of Exchange Rate on Tourism}

To better perceive the effectiveness of exchange rate on tourism in different countries, this section analyzes Turkey's experience in this regard. 
In developed countries, the tourism industry increases employment and leads to economic growth. According to the latest statistics published by the United Nations World Tourism Organization (UNWTO), one out of every 11 working individuals works directly or indirectly in a sector which provides finance or services for the tourism sector in every country. The growth of this sector, having many positive impacts on a country's economic growth, is supported by many channels including climatic and geographical features as well as historical sights. According to previous studies, the value of a country's currency is one of the factors attracting tourists to that country. Within this framework, in underdeveloped and developing countries, the tourism sector attracts tourists who bring currency to those countries. As a result, the value-added increase. This is why tourism is so much important.

According to the information data of official centers in Turkey, the Turkish lira has fallen short of value in comparison with global currencies in recent years. Nonetheless, it appears that Turkey's tourism industry has managed to benefit from good potentials because trips to Turkey, especially for the tourists of wealthy countries such as Germany, have become very cheap. Therefore, there have been more demands for trips to Turkey. According to the available statistics, the number of tourists visiting Turkey reached nearly 35 million individuals in 2013. This number increased to 37 million tourists in 2014 and did not decrease until some security and political problems occurred in Turkey. Despite all of these problems, Turkey managed to attract more than 25 million tourists in 2017. Nevertheless, infrastructures have had a significant role in attracting this large number of tourists. According to reputable data, one Turkish lira was nearly equivalent to $\$ 0.67$ in January 2010 ; however, the exchange rate decreased so significantly over time that one Turkish lira was nearly equivalent to $\$ 0.29$ in August 2017. In addition, one Turkish lira was nearly equivalent to 0.42 euros in 2013; however, it has reached 0.24 euros over time. This can help Turkey experience the good old days in the tourism industry and encourage European and North American tourists visit this country (GHARAMALEKI, 2018). 


\subsection{Relationship between Exchange Rate and Tourism}

Exchange rate volatility brings about a series of different and even contradictory changes to both domestic and foreign sectors of an economy which can have positive and negative impacts on a country's economic performance. Therefore, in the present century, no indices but the exchange rate volatility could attract economists and policymakers of developed and developing countries. The abnormal shock of the currency exchange system is an economic problem in each country. It can disrupt economic stability and decreases the relative purchase power in comparison with international balance (EBRAHIMI \& PEDRAM, 2014).

Therefore, the tourism revenue generation can greatly be affected by exchange rate shocks, a problem which is considered very important. Hence, many countries fixate their currencies against important currencies in an effort to prevent exchange rate shocks. However, some other countries have accepted the exchange rate shocks and adopted relevant policies (PANAHI et al., 2017).

If the exchange rate increases in the destination country, tourism production and services must become cheap for foreign tourists. In other words, foreign tourists can benefit from more goods and services at the previous price (in a specific exchange rate). This can encourage foreign tourists to visit that country. By contrast, if the exchange rate decreases, the arrival of foreign tourists will plummet. As a result, domestic tourists will leave their homelands to visit foreign countries because foreign goods and services will be cheaper to domestic tourists, something which increases the demands for foreign travel. In fact, the exchange rate volatility is a decisive factor in the long-term demands for tourism. If risk-avoiding tourists see the exchange rate volatility as high in a destination country, they might cancel or postpone their trips. They may also change their destinations to other countries. In addition, the exchange rate volatility might also reflect the social instability of the destination country, which may frighten foreign tourists (NIAZI \& REZAEI, 2015). 
According to the conventional theories, the decreased value of a country's currency in comparison with foreign currencies and the increased exchange rate are among the factors improving the tourism payment balance. After the collapse of the Burton Woods system in 1973 when the floating currency system was created, the analysis of time paths of exchange rate shocks and their effects on the payment balance trends indicate that the conventional theory of positive effectiveness of the increased exchange rate on the minimum tourism payment balance has short-term effects. This time path of change in the current status is the J curve. The difference in temporal reactions of payment balance from the actual volatility of monetary value and exchange rate will result in a J curve, according to which it is expected that the tourism payment balance will improve (the ascending part of a J curve) in the long run by decreasing the domestic currency value. However, this trend will not be true in the short run (the descending part of a J curve).

According to the theory of actual effective exchange rate, there is an important relationship between the actual effective exchange rate and business balance of a country. It is empirically evident that weakening a domestic currency and increasing the exchange rate will immediately worsen the current status. However, things improve after a few periods of insolvency. An important topic of international business is always the analysis of the relationship between the business balance with other effective variables. Nonetheless, if the emphasis is given only to the relationship between the exchange rate and business balance, then two general approaches can be taken into account: Marshal Learner's approach and J curve approach. To explain the first approach, it is fair to state that Leonard and Stockman (2011) conducted a few studies and concluded that Marshal Learner's condition was no longer able to explain the exact reaction of a country's business balance to exchange rate volatility. Therefore, studies of the two recent decades employed the J curve approach, which lays the applied foundations for the right attitudes towards the reactions of business balance to exchange rate volatility (RAJABIAN \& SALIMIFAR, 2015). 


\section{RESEARCH METHODOLOGY}

This is an applied study because the research results can be used in the decisions made by high-rank officials of Iran. It is also a descriptive-correlational study because the correlation coefficients of regression techniques were employed in this study to discover the relationships of research variables. In addition, it is a cross-sectional study because the research results will be achieved by testing available data.

According to Agiomirgianakis et al. (2016), the following regression model was employed to analyze the effects of exchange rate and economic, political, cultural, infrastructural, and environmental indicators on tourism:

Tourism $t=c_{0}+c_{1}$ EXR $t+c_{2}$ Economical $t+c_{3}$ Political $t+c_{4}$ Cultural $t+c_{5}$ Infrastructuret $+\mathrm{c}_{6}$ Environmental $\mathrm{t}+\mathrm{e}_{\mathrm{t}}$

\subsection{Dependent Variable}

Tourism: this variable indicates the tourism revenue.

\subsection{Independent Variables:}

EXR: this variable shows the actual exchange rate. 
Economical: this is the economic composite indicator including certain variables such as economic growth rate, inflation rate, direct foreign investment, business openness degree, the number of foreign tourists, and the state scale. The economic composite indicator is constructed in the following way:

\begin{tabular}{|c|c|c|}
\hline $\begin{array}{c}\text { Sub- } \\
\text { indicator }\end{array}$ & Construction method & Value \\
\hline 1 & $\begin{array}{l}\text { If economic growth is positive in current year compared to } \\
\text { the previous year, the value is one; otherwise, the value is } \\
\text { zero. } \\
\text { If the inflation rate of the current year is higher than that } \\
\text { of the previous year, the value is one; otherwise, the value } \\
\text { is zero. }\end{array}$ & $\begin{array}{c}\text { Summation of } \\
\text { values on first } \\
\text { and second } \\
\text { axes }\end{array}$ \\
\hline 2 & $\begin{array}{l}\text { If the direct foreign investment of the current year is } \\
\text { greater than that of the previous year, the value is one; } \\
\text { otherwise, the value is zero. } \\
\text { If business openness degree of the current year is greater } \\
\text { than that of the previous year, the value is one; otherwise, } \\
\text { the value is zero. }\end{array}$ & $\begin{array}{c}\text { Summation of } \\
\text { values on first } \\
\text { and second } \\
\text { axes }\end{array}$ \\
\hline 3 & $\begin{array}{l}\text { If the number of foreign tourists is higher in this year than } \\
\text { the previous year, the value is one; otherwise, the value is } \\
\text { zero. } \\
\text { If the state scale is larger in the current year than in the } \\
\text { previous year, the value is one; otherwise, the value is } \\
\text { zero. }\end{array}$ & $\begin{array}{c}\text { Summation of } \\
\text { values on first } \\
\text { and second } \\
\text { axes }\end{array}$ \\
\hline
\end{tabular}

Political: this is the political composite indicator including certain variables such as sanctions and risks. This indicator is constructed in the following way:

\begin{tabular}{ccc}
\hline $\begin{array}{c}\text { Sub- } \\
\text { indicator }\end{array}$ & Construction method & Value \\
\hline 1 & If the US imposes more sanctions on Iran in the current & Summation of \\
year, the value is one; otherwise, the value is zero. & values on first \\
If Iran's corruption score is larger this year than the & and second \\
previous year, the value is one; otherwise, the value is & axes \\
& & \\
& & \\
&
\end{tabular}


Cultural: this is the cultural composite indicator including certain variables such as the number of published books and ........ This indicator is constructed in the following way:

\begin{tabular}{|c|c|c|}
\hline $\begin{array}{c}\text { Sub- } \\
\text { indicator }\end{array}$ & Construction method & Value \\
\hline 1 & $\begin{array}{c}\text { If there are more cultural-artistic centers this year than the } \\
\text { previous year, the value is one; otherwise, the value is } \\
\text { zero. } \\
\text { If there are more books published this year than the } \\
\text { previous year, the value is one; otherwise, the value is } \\
\text { zero. }\end{array}$ & $\begin{array}{c}\text { Summation of } \\
\text { values on first } \\
\text { and second } \\
\text { axes }\end{array}$ \\
\hline
\end{tabular}

Infrastructure: this is the infrastructural composite indicator including certain variables such as road, railroad, and air infrastructures as well as transportation and health systems, hotels, and accommodations. This indicator is constructed in the following way:

\begin{tabular}{|c|c|c|}
\hline $\begin{array}{c}\text { Sub- } \\
\text { indicator }\end{array}$ & Construction method & Value \\
\hline 1 & $\begin{array}{l}\text { If transportation infrastructures have been expanded } \\
\text { more widely this year than the previous year, the value is } \\
\text { one; otherwise, the value is zero. } \\
\text { If transportation systems have been expanded more } \\
\text { widely this year than the previous year, the value is one; } \\
\text { otherwise, the value is zero. } \\
\text { If the health system has been expanded more widely this } \\
\text { year than the previous year, the value is one; otherwise, } \\
\text { the value is zero. }\end{array}$ & $\begin{array}{c}\text { Summation of } \\
\text { values on first } \\
\text { and second } \\
\text { axes }\end{array}$ \\
\hline
\end{tabular}


Environmental: this is the environmental composite indicator including certain variables such as fires in forests and plains as well as air cleanliness. This indicator is constructed in the following way:

\begin{tabular}{ccc}
$\begin{array}{c}\text { Sub- } \\
\text { indicator }\end{array}$ & Construction method & Value \\
\hline 1 & $\begin{array}{c}\text { If there are more fires in forests and plains this year than } \\
\text { the previous years, the value is one; otherwise, the value is } \\
\text { zero. }\end{array}$ & $\begin{array}{c}\text { Summation of } \\
\text { values on first } \\
\text { and second } \\
\text { axes }\end{array}$ \\
& $\begin{array}{c}\text { If the emission rate of gas pollutants (CO) is higher this } \\
\text { year than the previous year, the value is one; otherwise, } \\
\text { the value is zero. }\end{array}$ & \\
\hline
\end{tabular}

e: this indicator shows the error component.

The econometric models of time series were employed to estimate the research model. Then a VAR model was utilized to determine the exchange rate shocks. The data were collected merely through a desk method by taking notes of references and gathering information from reputable websites of available sources (e.g. Iran's Central Bank; Iran's National Statistic Center; Cultural Heritage, Handicrafts, and Tourism Organization of Iran, and the World Bank) from 1981 to 2018. All of the computations and analyses were performed in Excel and Eviews10.

\section{DATA ANALYSIS}

\subsection{Reliability Test}

Before the model is estimated, it is necessary to check the reliability of variables with respect to the fact that the research data are of time series. The Dickey-Fuller test is a type of reliability check employed in this study. Table 1 shows the reliability test results: 
Table 1 - Reliability Test Results

\begin{tabular}{cccccc}
\hline & \multicolumn{2}{c}{ Surface Reliability Test } & Surface Reliability Test & \\
\cline { 2 - 4 } Result & Probability & $\begin{array}{c}\text { ADF } \\
\text { statistic }\end{array}$ & Probability & $\begin{array}{c}\text { ADF } \\
\text { statistic }\end{array}$ & Variable \\
\hline $\begin{array}{c}\text { Reliable with one } \\
\text { difference }\end{array}$ & 0.1025 & -3.19 & 0.2944 & -2.57 & Tourism \\
\hline $\begin{array}{c}\text { Reliable with one } \\
\text { difference }\end{array}$ & 0.0034 & -4.67 & 0.0288 & -3.86 & EXR \\
\hline
\end{tabular}

Source: Research findings

According to the above table, the statistics of tests and critical values show that Tourism and EXR were not reliable at surface and became reliable making one differentiation.

\subsection{Determining the Optimal Model Interruption}

In the next step, the number of optimal interruptions was determined in the research model. The Akaike, Hannan-Quinn, and LR information criteria were employed to determine the optimal interruptions. Table 2 shows the results of the optimal interruption test:

Table 2 - Results of Determining Optimal Interruptions

\begin{tabular}{cccc}
\hline LR & HQ & AIC & $\begin{array}{c}\text { Number of } \\
\text { Interruptions }\end{array}$ \\
\hline- & 56.05748 & 56.02696 & No interruptions \\
\hline 106.2824 & 52.81819 & 52.72664 & One interruption \\
\hline 7.427734 & 52.85637 & 52.70379 & Two interruptions \\
\hline 5.077328 & 52.96455 & 52.75093 & Three interruptions \\
\hline $11.12191 *$ & $52.80459 *$ & $52.52994^{*}$ & Four interruptions \\
\hline
\end{tabular}

Source: Research Findings 
According to the above criteria, four interruptions were selected as the optimal number of interruptions in the model.

\subsection{VAR Model Estimation}

According to Table 2, four interruptions were considered optimal. Table 3 shows the results of estimating the VAR model based on four interruptions:

Table 3- Results of Estimating the VAR Model

To be Continued

\begin{tabular}{ccc}
\hline Exchange Rate & Tourism Revenue & Variables \\
\hline EXR & LOG(TOURISM) & \\
\hline 4.840812 & 0.330736 & \\
$(22.3469)$ & $(0.22908)$ & LOG(TOURISM(-1)) \\
{$[0.21662]$} & {$[1.44373]$} & \\
\hline 0.451314 & 0.150554 & \\
$(21.7893)$ & $(0.22337)$ & LOG(TOURISM(-2)) \\
{$[0.02071]$} & {$[0.67402]$} & \\
\hline-12.44062 & 0.188121 & \\
$(21.5449)$ & $(0.22086)$ & LOG(TOURISM(-3)) \\
{$[-0.57743]$} & {$[0.85176]$} & \\
\hline-0.106604 & 0.290617 & \\
$(18.9137)$ & $(0.19389)$ & LOG(TOURISM(-4)) \\
{$[-0.00564]$} & {$[1.49889]$} & \\
\hline 0.858944 & 0.003580 & EXR(-1) \\
$(0.24273)$ & $(0.00249)$ & \\
{$[3.53867]$} & {$[1.43863]$} & EXR(-4) \\
\hline-0.351686 & -0.006108 & \\
$(0.33072)$ & $(0.00339)$ & EXR(-3) \\
{$[-1.06338]$} & {$[-1.80171]$} & \\
\hline 0.053158 & 0.004283 & \\
$(0.32287)$ & $(0.00331)$ & \\
{$[0.16464]$} & {$[1.29408]$} & $-1.60086]$ \\
\hline 0.039829 & -0.003543 & \\
$(0.21590)$ & $(0.00221)$ & \\
{$[0.18448]$} & & \\
\hline & & \\
\hline
\end{tabular}


Table 3- Results of Estimating the VAR Model

Conclusion

\begin{tabular}{ccc}
\hline Exchange Rate & Tourism Revenue & Variables \\
\hline EXR & LOG(TOURISM) & \\
\hline 4.403253 & 0.090535 & \\
$(11.0408)$ & $(0.11318)$ & ECONOMICAL \\
{$[0.39882]$} & {$[0.79991]$} & \\
\hline 8.512811 & -0.147012 & \\
$(14.0074)$ & $(0.14359)$ & POLITICAL \\
{$[0.60774]$} & {$[-1.02381]$} & \\
\hline-19.21138 & 0.169726 & \\
$(26.8074)$ & $(0.27481)$ & CULTURAL \\
{$[-0.71664]$} & {$[0.61761]$} & \\
\hline 9.666610 & -0.064776 & \\
$(27.2435)$ & $(0.27928)$ & INFRASTRUCTURE \\
{$[0.35482]$} & {$[-0.23194]$} & \\
\hline-14.77873 & 0.126994 & \\
$(27.5394)$ & $(0.28231)$ & ENVIRONMENTAL \\
{$[-0.53664]$} & {$[0.44983]$} & \\
\hline 0.670588 & 0.945649 & R-squared \\
\hline 0.445200 & 0.908462 & Adj. R-squared \\
\hline 2.975266 & 25.42942 & F-statistic \\
\hline
\end{tabular}

Legend: The values between parentheses show the standard errors, and the values between brackets show the $t$ statistics.

Source: Research findings

The estimated function forms of the tourism revenue and the exchange rate are as follows:

$\operatorname{LOG}($ TOURISM) $=0.879139+0.330736 * \operatorname{LOG}($ TOURISM(-1)) +0.150554 * LOG(TOURISM(-2)) + 0.188121* LOG(TOURISM(-3)) + 0.290617* LOG(TOURISM(-4)) + $0.003580 * \operatorname{EXR}(-1)-0.006108 * \operatorname{EXR}(-2)+0.004283 * \operatorname{EXR}(-3)-0.003543 * \operatorname{EXR}(-4)+$ 0.090535* ECONOMICAL - 0.147012* POLITICAL + 0.169726* CULTURAL- 0.064776* INFRASTRUCTURE + 0.126994* ENVIRONMENTAL 
EXR $=189.6903+4.840812$ LOG(TOURISM(-1)) +0.451314 * LOG(TOURISM(-2)) -12.44062 * LOG(TOURISM(-3)) -0.106604 * LOG(TOURISM(-4)) + 0.858944 * EXR(-1) 0.351686 * $\operatorname{EXR}(-2)+0.053158$ * $\operatorname{EXR}(-3)+0.039829$ * $\operatorname{EXR}(-4)+4.403253$ * ECONOMICAL + 8.512811 * POLITICAL -19.21138 * CULTURAL+ 9.666610 * INFRASTRUCTURE -14.77873 * ENVIRONMENTAL

According to the above table, the values of $\mathrm{R} 2$ for the tourism and exchange rate equations were 0.94 and 0.67 , respectively, showing the explanatory power of these models. In addition, given the value of the computational F statistic, it is observed that the estimated regression equations are statistically significant. Other results indicate the following conclusions briefly:

In the tourism revenue equation, certain variables such as the tourism revenue logarithm with one, two, three, and four interruptions, the exchange rate with one and three interruptions, composite indicators of economic, cultural, and environmental factors had positive effects on the tourism revenue logarithm, regarded as the dependent variable. However, other variables including the exchange rate with two and four variables and composite indicators of political and infrastructural factors had negative impacts on the tourism revenue logarithm, regarded as the dependent variable.

In the exchange rate equation, certain variables including the tourism revenue logarithm with one and two interruptions, the exchange rate with one, two, and four interruptions, and composite factors of economic, political, and infrastructural factors had positive effects on the exchange rate, regarded as the dependent variable. However, certain variables such as the tourism revenue logarithm with three and four interruptions, the exchange rate with two interruptions, and composite factors of cultural and environmental indicators had negative impacts on the tourism revenue logarithm, regarded as the dependent variable. 


\section{CONCLUSION}

According to the empirical research findings, the exchange rate had a significant impact on touring in Iran. In other words, if the exchange rate of a destination country increases, the goods and services will be inexpensive to foreign tourists in that country. In fact, foreign tourists can benefit from more goods and services by spending the same amount of money (in currency), something which encourages them to travel to that country. On the contrary, this can make domestic tourists travel to foreign countries because foreign goods and services will be inexpensive to domestic tourists when the exchange rate decreases, something which increases the demands for trips abroad. Therefore, the exchange rate can affect a country's tourism revenue. It was also observed that economic, political, cultural, infrastructural, and environmental composite indicators had significant effects on the tourism revenue in Iran.

According to the research findings, the following suggestions are made:

- Currency policymakers should always monitor currency policies and exchange rate volatility to alleviate the damage posed to different economic sectors such as tourism.

- Economy officials should always regard economic, political, cultural, infrastructural, and environmental macro indicators as their policymaking priorities because these variables can affect the international tourism revenue in addition to the domestic conditions.

\section{REFERENCES}

EBRAHIMI, M., PEDRAM, M. Analyzing Importance and Effectiveness of Economic Variables on Exchange Rate in Iran. Economic Development Policy, Al-Zahra University, 2(3), 141-168, 2014.

ERGEN, E., YAVUZ, E. Empirical Analysis of the Relationship between Tourist Flows and Exchange Rate Volatility: ARDL Method, International Journal of Economics and Innovation, 3(1), 35-46, 2017. 
FATAHI, S. Advantages of Islamic Tourism Industry on Iran's Economy and Culture. April 29, 2017.

GEORGE, A., AND DIMITRIOS, S., AND NICHOLAS, T. "Effects of Exchange Rate Volatility on Tourist Flows into Iceland", Procedia Economics and Finance, 24, 25-34, 2016.

GHARAMALEKI, H. Effect of Increased Exchange Rate on Turkey's Tourism Industry. Karabük University, 2018.

MASOUM ZADEH, S., SHIRAFKAN LAMSOU, M. Analyzing Effects of Exchange Rate Regimes on International Tourism Flow in Selected Islamic Countries: Gravity Approach. Urban Tourism, 4(4), 73-89, 2017.

MOHAMMADI, E. A. Factors Affecting Tourism Demands in Iran. Economic Sciences, 3(10), 127-136, 2010.

NIAZI, E., REZAEI, GH. Effect of Exchange Rate Shock on International Tourism Flow in Iran. Second National Tourism Conference, National Capitals and Future Outlook, 2015.

OGBEBA EHIGOCHO, P., OJI-OKORO, I., AND ABBA ABUBAKAR, S. “Exchange Rate Fluctuation and Tourism Sector Output in Nigeria", International Journal of Management Science and Business Administration 3(1), 48-55. DOI:

10.18775/ijmsba.1849-5664-5419.2014.31.1005, 2016.

PANAHI, H., MASOUM ZADEH, S., RAZAGHI, S. Analyzing Effect of Exchange Rate on Iran's Tourism Payment Balance. Applied Theories of Economy, 4 (2), 98-112, 2017.

RAJABIAN, M. A; SALIMIFAR, M. Effect of Actual Exchange Rate on Non-Oil Trade Balance: Iran-Turkey Empirical Comparison. Rahbord, 24 (77), 275-294, 2015.

RASEKHI, S., MOHAMMADI, S. Factors Affecting Tourism Demands in the Caspian Sea Countries. Tourism Management Studies, 12 (38), 67-89, 2017.

TAMIZI, A., SHAHBAZI, S. Analyzing Effect of Exchange Rate Volatility on Iran's Tourism Sector. Scientific and Research Seasonal Journal of Tourism and Development, 7 (4), 117, 2018. 


\section{AUTHORSHIP CONTRIBUTION}

\section{1- Ali Sarchami: Validation:}

PhD Student

https://orcid.org/0000-0001-8370-2128 | E-mail: Alisarchami@yahoo.com

Contribuition: Data curation, Formal Writing - original draft, Analysis, Funding acquisition, Resources

\section{2- Mohsen Zayandehrodi:}

Associate professor

https://orcid.org/0000-0003-0307-514X | E-mail: M_roody2000@yahoo.com

Contribuition: Project administration, Writing - review \& editing, Investigation, Visualization, Methodology

\section{3- Seyyed Abdulmajid Jalaee:}

Professor

https://orcid.org/0000-0003-0852-0337 | Jalaee@uk.ac.ir

Contribuition: Conceptualization, Supervision, Software

\section{HOW TO QUOTE THIS ARTICLE}

SARCHAMI, A; ZAYANDEHRODI, M; JALAEE, S. A. Impacts of Exchange Rate and Economic, Political, Cultural, Infrastructural, and Environmental Indicators on Tourism in Iran. Santa Maria, v.25, e11, 2021. Available from: https://doi.org/10.5902/2236117063797. Accessed: Month Abbreviated. Day, year. 